\title{
位相制御レーザーパルスによる配向分子選択イオン化
}

\author{
大 村 英 樹*1
}

\section{Selective Ionization of Oriented Molecules by Phase-controlled Laser Fields Hideki OHMURA}

National Institute of Advanced Industrial Science and Technology (AIST), 1-1-1 Higashi, Tsukuba, Ibaraki, 305-8565, Japan

(Received June 30, 2010, Accepted August 7, 2010)

\begin{abstract}
Intense $\left(10^{12}-10^{13} \mathrm{~W} / \mathrm{cm}^{2}\right)$ phase-controlled laser fields consisting of a fundamental light and a second-harmonic light induce the directionally asymmetric tunneling ionization and the resultant selective ionization of oriented molecules. It is demonstrated that selective ionization of oriented molecules induced by phase-controlled $\omega+2 \omega$ laser fields reflects the geometric structure of the highest occupied molecular orbital. This method was robust, being free of both laser wavelength and pulse-duration constraints, and thus can be applied to a wide range of molecules.
\end{abstract}

\section{1. はじめに}

気体や液体の物性計測において，分子はランダムな速度， 配向で飛び回っているため, 測定結果は速度分布や配向分布 の影響を伴うことは避けられない。分子の運動状態（並進， 振動, 回転) を単一化できれば解析可能な情報量は飛躍的に 増え, 高度な計測が可能となる. 反応制御や物質合成につい ても状況は類似しており, 現行プロセスの低収率, 低選択性 の原因は分子の運動状態の分布によるところが大きい. 分子 の運動状態の単一化操作は, 状態選択型のプロセス技術を用 いた機能性材料の創生にとってのキーテクノロジーとなる.

超音速分子線は, 断熱膨張により並進エネルギーが単一化 して抢り, 気相反応, 固体表面反応の研究ツールとして広く 利用されてきた. 最近では, 電場, 磁場, レーザー光, 分子 衝突効果等を利用することにより, 並進エネルギーのみなら ず，分子の配向方向も単一化した配向分子線の発生とそれを 用いた化学反応の研究が精力的に進められてきた ${ }^{1-4)}$. 反応 機構, 反応速度, 反応分岐比は, 化学種のどの部分が互いに 接して化学結合を形成するかという分子配向依存性に基づく 「立体効果」に大きく依存し, それらを研究する分野は立体 化学とよばれている. 配向分子線の発生技術が進展したこと により，化学反応の多様性を量子力学的な精密さで解明する 道が開けた．超音速分子線を外場と相互作用させることによ って, いくつかの配向分子線発生法が発展している. (1)分子 と六極不均一電場との相互作用の利用 1,2$)$ : 不均一電場によ るシュタルク効果によって引き起こされる回転量子状態の分 裂とその選別に基づいており, 高い配向度状態の定常的な実 現が可能である. 適用可能な分子が対称コマ分子に限定され る等の制約がある. (2)強い静電場と分子との相互作用の利 用: 強い静電場中で分子が振り子運動することを利用したも ので, 原理的には, 回転温度の低い極性分子に広く適用可能 で定常的な配向状態の実現が可能である. 配向状態は分子線 の回転温度に敏感であり, 実際に得られる配向度が低く測定 される立体効果は僅かであることが多い。(3)強いレーザー場 と分子との相互作用を利用 ${ }^{4)}$ : 分子の分極と非共鳴の高強度

*1 産業技術総合研究所（干305-8565 茨城県つくば市東 1-1-1）
レーザー光による光電場との相互作用によって分子にトルク がかかり, 分子がレーザーの偏光方向に配向するというもの である. 分子の回転周期とレーザーの時間幅との大小関係で 分子配向の物理的状況が異なる. 分子の回転周期に比べて レーザーの時間幅が十分に長い場合, 分子配向はレーザーパ ルスの包絡線に追従してゆっくり断熱的に発展していく（断 熱分子配向). 分子の回転周期にくらべてレーザーの時間幅 が十分短い場合, 回転波束が形成され, レーザーパルスの通 過後, 回転周期の整数倍または分数倍の時刻で分子が配向す る (非断熱分子配向).レーザーの集光された極微小領域に おいてパルスの時間幅程度の極短時間しか配向を保持できな いため, 超高速光化学反応過程や軟 X 線アト秒パルスや高 調波発生において利用されているが, 衝突をともなう立体効 果の研究への適応は限られている.

気相分子の分子配向に関する一般論として，分子を担持し てその配向を揃えるという方法が取れない気相分子集団に対 して，高い配向度でしかもその配向状態を非接触で定常的に 保持することは，原理的，技術的に極めて困難である.さら に立体化学の分野において, 単純な系での量子力学に基づく 精密実験と同様に重要な対象は, 酵素などの生体分子の立体 効果に代表される 3 次元的な分子配向に関する立体効果で あろう。ある程度大きな分子の化学反応の多様性を解明する ためには, 異方性のある分子を対象とした 3 次元的かつ配 向度の高い配向分子線が必要となる.しかしながら 3 次元 的な分子配向は, 配向制御が容易な分子軸に加え, 制御が困 難な分子軸も対象となるため, それぞれ単一の配向分子線発 生法では配向度の高い 3 次元分子配向は原理的, 技術的に 非常に困難である場合が多い。したがって, 新しい原理に基 ゔく汎用性のある配向制御法, または原理の異なる配向分子 線発生技術の組み合わせによる配向度の高い 3 次元分子配 向制御技術が期待される.

最近，筆者はレーザー光の基本波と第二高調波から構成さ れる強い $\left(10^{12} \sim 10^{13} \mathrm{~W} / \mathrm{cm}^{2}\right)$ 位相制御レーザーパルスに よる気体分子の（頭と尻尾を区別した）配向分子選択イオン 化に成功した ${ }^{5-12)}$. 通常のレーザー光では困難であった頭と 尻尾を区別した分子操作が位相制御レーザーパルスを用いる ことによって可能となり, 配向分子の向きを基本波と第二高 
調波の相対位相差によって反転できることを明らかにした. あとで説明するように分子の最外殼軌道（HOMO）と位相 制御レーザーパルスの異方的光電場との高次非線形相互作用 によって引き起こされる異方性光トンネルイオン化に基づく 光による空間領域での波動関数選択による分子操作である. いくつかの制約はあるが新しい原理に基づく分子操作技術で あるため, 従来の配向分子線発生技術と組久合わせることが 可能である. 本稿では, 位相制御レーザーパルスの特徵, 異 方性光トンネルイオン化と配向分子選択効果, 実験方法と実 験結果について述べる.

\section{2. $(\omega+2 \omega)$ 位相制御レーザーパルスによる異方 性トンネルイオン化と配向分子選択効果}

レーザー光の基本波（周波数： $\omega$ ) と第二高調波（周波数： $2 \omega)$ を重ね合わせて, その相対位相差 $\phi$ を精密に制御した 位相制御レーザー光 $\mathrm{E}(\mathrm{t})$ （以下 $(\omega+2 \omega)$ 位相制御レーザー 光) $E(t)=E_{1} \cos (\omega t)+E_{2} \cos (2 \omega t+\phi)$ を考える. ここ で $E_{1}, E_{2}$ はそれぞれ基本波と第二高調波の光電場振幅であ る. Fig. 1 (a) に示すように相対位相差 $\phi$ がゼロまたは $\pi$ の 場合，その光電場波形は正負の振幅が異なるために非対称な 形状となる. $(\omega+2 \omega)$ 位相制御レーザー光は正負を区別で きない通常の光電場とは異なり静電場的な方向性が生じる. この非対称性は，位相差をゼロから る.このように $(\omega+2 \omega)$ 位相制御レーザー光は非対称光 電場で特徵付けられ, 従来の光とは本質的に異なる性質を示 す.

原子や分子が強いレーザー光によって励起された場合，イ オン化ポテンシャルよりも十分小さい光子エネルギーでも非 共鳴イオン化される，レーザー強度をI，イオン化ポテンシ ヤルを $\mathrm{I}_{\mathrm{p}}$, レーザー波長を $\lambda$, 光速を c とすると, Keldysh パラメター $\gamma=2 \pi \mathrm{c} / \lambda\left(2 \mathrm{I}_{\mathrm{p}} / \mathrm{I}\right)^{1 / 2}$ によってイオン化過程は $2 つ$ の領域に分類される ${ }^{13)} \cdot \gamma>1$ の領域では光学遷移の概念が 有効であり，イオン化過程は分子が複数の光子を吸収する多 光子イオン化によって記述できる.さらにレーザー強度が大 きくなり $\gamma<1$ の領域になると, 光学遷移の描像よりは光電 場によって駆動される電子や分極といった古典力学的な描像 の方が物理現象を理解しやすくなる．このレーザー強度領域 では原子や分子はトンネルイオン化することが知られてい る. 束縛電子のポテンシャルが光電場で歪むことによってそ の障壁が下がり, 電子がポテンシャル障壁をトンネルするこ とによりイオン化する. 分子のトンネルイオン化を記述する 分子 Ammosov-Delone-Krainov（ADK）モデルによると， 分子の最外殼軌道 (HOMO) から電子が引き抜かれイオン 化が起こるが，波動関数の空間的に広がったところから電場 に沿って電子が引き抜かれる確率が高くなる14-16)。 その結 果，イオン化確率において分子と光電場との角度依存性が生 じるため，光解離生成物の放出角度分布は HOMO の空間形 状を反映したものになることが理論的に示されており ${ }^{14,15)}$, 実験でも実際に観測されている16)。例えば， $\sigma$ 軌道の $\mathrm{HOMO}$ をもつ窒素分子では HOMO の形状を反映したダン ベル型の放出角度分布が， $\pi$ 軌道の HOMO を持つ酸素分子 では HOMO の空間形状を反映したバタフライ型の放出角度 (a)

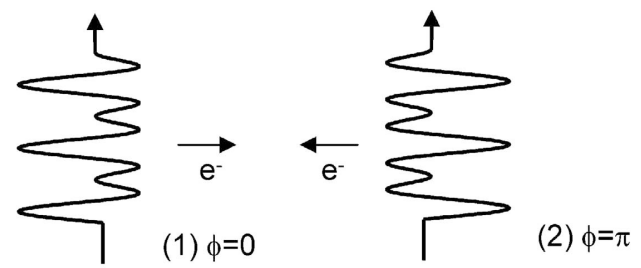

(b)
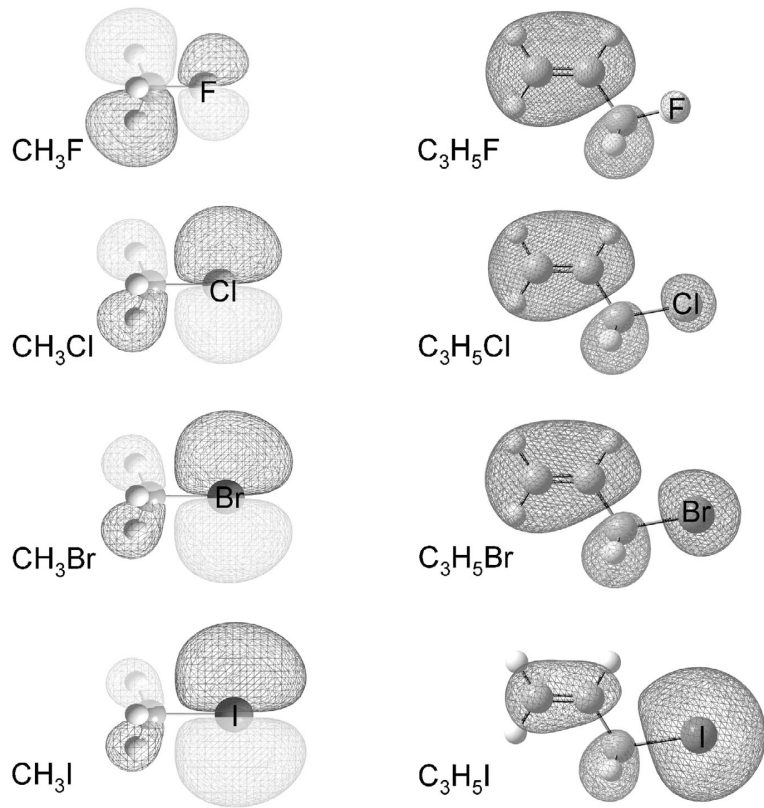

Fig. 1 (a) Waveforms of phase-controlled two-color $\omega+2 \omega$ laser fields at relative phase differences (1) $\phi=0$ and (2) $\phi=$ $\pi$. (b) Molecular structure and isocontour of the highest occupied molecular orbital (HOMO) of (left) $\mathrm{CH}_{3} \mathrm{X}(\mathrm{X}=\mathrm{F}, \mathrm{Cl}$, $\mathrm{Br}, \mathrm{I})$ and (right) $\mathrm{C}_{3} \mathrm{H}_{5} \mathrm{X}(\mathrm{X}=\mathrm{F}, \mathrm{Cl}, \mathrm{Br}, \mathrm{I})$ as determined by $a b$ initio calculations using the Gaussian $03 \mathrm{~W}$ software package (method: MP2; basis sets: $6-31++\mathrm{G}\left(2 \mathrm{df}\right.$, p) for $\mathrm{CH}_{3} \mathrm{~F}$, $\mathrm{CH}_{3} \mathrm{Cl}, \mathrm{C}_{3} \mathrm{H}_{5} \mathrm{~F}, \mathrm{C}_{3} \mathrm{H}_{5} \mathrm{Cl}$ and LanL2DZ augmented by polarization functions and diffuse functions for $\mathrm{CH}_{3} \mathrm{Br}, \mathrm{CH}_{3} \mathrm{I}, \mathrm{C}_{3} \mathrm{H}_{5} \mathrm{Br}$, $\mathrm{C}_{3} \mathrm{H}_{5} \mathrm{I}$ ). The shadings indicate the signs of the wave functions.

分布が観測されている16).

Fig. 1(b)に示されるはハロゲン化メチル $\left(\mathrm{CH}_{3} \mathrm{X} ; \mathrm{X}=\mathrm{F}\right.$, $\mathrm{Cl}, \mathrm{Br}, \mathrm{I})$ や八ロゲン化アリル $\left(\mathrm{C}_{3} \mathrm{H}_{5} \mathrm{X} ; \mathrm{X}=\mathrm{F}, \mathrm{Cl}, \mathrm{Br}, \mathrm{I}\right)$ の ような非対称な HOMO と $(\omega+2 \omega)$ 位相制御レーザーパル スの非対称光電場が高次非線形相互作用を起こすと，非対称 な波動関数においてに空間的に広がった方から非対称光電場 の最大の方向に異方的なトンネルイオン化が起こる確率が高 くなるため，ランダム配向の気体分子集団の中から（頭と尻 尾を区別した）配向分子だけが選択的にイオン化される．最 近，高強度レーザーによる光トンネルイオン化の時間領域で の精密な実験が行われ，トンネルイオン化は光の 1 周期の 中で光電場の最大付近のアト秒領域で電子が引き抜かれてい ることが報告されている17,18). 非対称電場をもつ位相制御 レーザーパルスを用いることによって，光トンネルイオン化 の特徵であるアト秒時間領域での現象が空間異方性を伴って 発現する. 異方性光トンネルイオン化による配向分子選択効 果は，ある意味で時間，空間領域での分子制御の結果である と言える。 


\section{3. 実 験方法}

実験装置については，詳細は文献 $[11]$ に譲りここでは 簡単に紹介するにとどめる，実験装置は，(1)光源，(2)マッ ハーツェンダー干渉計，(3)質量分析用真空チェンバーから構 成される。光源は再生増幅されたTi:Sapphire レーザー (Spectra-Physics, Hurricane, 波長；800 nm，強度；10 14 $\mathrm{W} / \mathrm{cm}^{2}$ ，パルス幅；130 fs）を使用した。その出力の一部を 非線形光学結晶（BBO）で第 2 高調波に変換したあと, 基 本波と第二高調波の相対位相差 $\phi$ はマッハーツェンダー干 渉計で制御される(位相精度 ; $0.05 \pi$, 時間精度 ; 20 ア卜秒).

マッハーツェンダー干渉計は, 振動を遮断するために防振 台の上に設置されている．また大気の摇らぎを抑制するため 容器の中に設置されている。 マッハーツェンダー干渉計に て，基本波と第二高調波が分離されそれぞれ別の経路を通 り，第二高調波の経路には相対位相差 $\phi$ を制御するための 位相板が挿入されている. 位相板を回転させ入射角を変化さ せることにより相対位相差 $\phi$ を精密に制御することができ る. その後, 基本波と第二高調波は再び重ね合わせられる. その際，基本波と第二高調波は空間的に精密に重ね合わせる ことが要求されるが，基本波と第二高調波は干渉縞を形成し ないのでそのままでは空間的な重なりを評価することができ ない，そこで，評価用の第二の非線形光学結晶をマッハーツ エンダー干渉計の後に挿入し, 基本波の第二高調波を発生さ せる. 第一の非線形光学結晶で発生させた第二高調波と第二 の非線形光学結晶で発生させた第二高調波の干渉縞を観察す ることにより，空間的な重なりを評価することができる（測 定時には評価用の第二の非線形光学結晶は取り除かれる).

He ガスで希釈した気体試料は，超音速分子線として質量分 析用真空チェンバーに導入され，位相制御された光パルスが 照射される.

気体分子の分子配向の観測には，解離性イオン化反応を利 用する. 光強度が $10^{12} \sim 10^{13} \mathrm{~W} / \mathrm{cm}^{2}$ 程度に達すると, 分子 は非共鳴で光イオン化し解離生成物イオンを生成する解離性 イオン化反応を起こす. 生じた光解離生成物イオンを飛行時 間型質量分析装置にて検出する. 解離性イオン化反応が分子 の回転周期よりも十分短い時間で起こる場合，ある結合が切 断されて分子が 2 つの部分に分離して（2 体解離）生じた光 解離生成物イオンは結合軸に沿って放出されるため, 光解離 時の分子の配向方向と相関がある. 通常の気体分子はランダ 厶配向であるので，その光解離生成物の放出方向もランダム である.しかし特定の配向方向の分子だけが光解離した場 合, 光解離生成物の放出角度分布は, 配向方向を反映した特 徵的なものとなる. 二原子分子の配向方向を Fig. 2 (a) に示 されるようにイオン検出器の方向にとった場合, 光解離生成 物は飛行時間（time of flight; TOF）の関数としてプロット すると（TOF スペクトル），イオン検出器に直接向かう成分 （前方放出成分； $\mathrm{I}_{\mathrm{f}}$ ）とイオン検出器から一度遠ざかった後, 引き出し電極によってイオン検出器に導かれる成分（後方放 出成分； $\mathrm{I}_{b}$ ）のピークの対として観測される. 分子の頭と尻 尾を区別しない分子軸だけの整列の場合（分子整列）， $\mathrm{I}_{\mathrm{f}}$ と $\mathrm{I}_{\mathrm{b}}$ は等しくなるが頭と尻尾を区別した分子配向の場合， $\mathrm{I}_{\mathrm{f}}$ と (a)

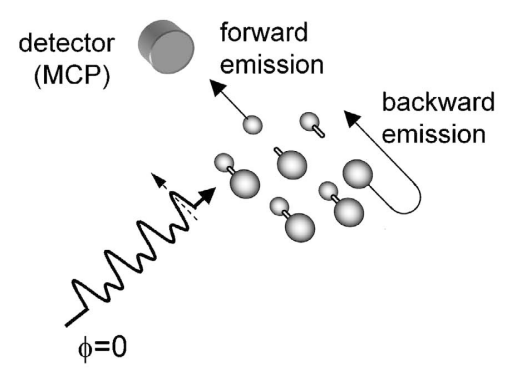

(b)

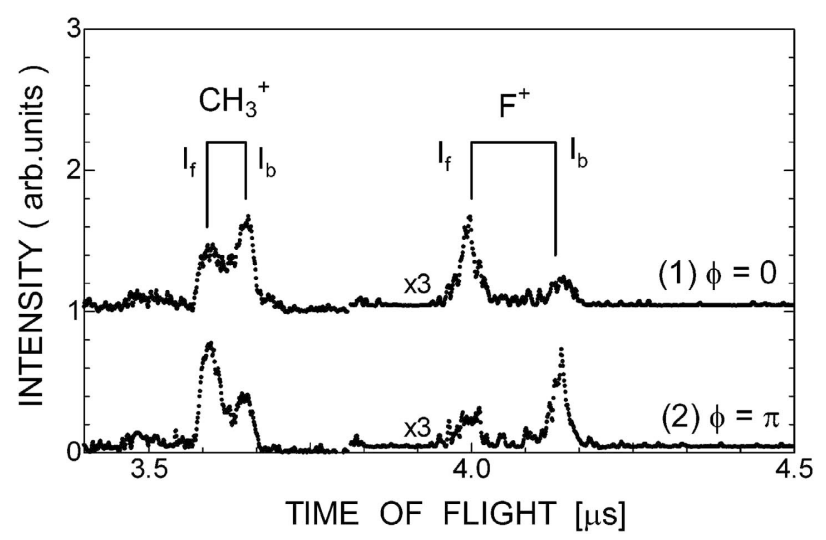

Fig. 2 (a) Schematic of the detection of the oriented molecular ions. We define the relative phase difference as $\phi=0$ when the electric field maxima point toward the detector (forward direction) and as $\phi=\pi$ when the electric field maxima point away from the detector (backward direction). (b) TOF spectra of the singly-charged ions produced by dissociative ionization of $\mathrm{CH}_{3} \mathrm{~F}$ molecules irradiated with phase-controlled $\omega+$ $2 \omega$ laser fields at the relative phase difference (1) $\phi=0$ and (2) $\phi=\pi$. The solid lines indicate pairs of forward and backward peak.

$\mathrm{I}_{\mathrm{b}}$ が異なりピーク対は非対称な形状となる．このピーク対の 非対称性から，気体分子の配向状態を計測することができ る*1.

Fig. 2(b)はフッ化メチルに $(\omega+2 \omega)$ 位相制御フェムト 秒光パルスを照射した時の TOF スペクトルである ${ }^{8)}$. 光解 離生成物イオンであるフッ素イオンとメチルイオンが観測さ れる。両者は $\mathrm{I}_{\mathrm{f}}$ と $\mathrm{I}_{\mathrm{b}}$ の対として観測され，ピークの間隔は 光解離時の運動エネルギーを反映している．基本波と第二高 調波との相対位相差 $\phi=0$ の場合, フッ素イオンでは $\mathrm{I}_{\mathrm{f}}$ が， メチルイオンでは $\mathrm{I}_{\mathrm{b}}$ が大きく観測される. 一方, 相対位相

*1 ここで報告する実験結果は，2 価の親分子および 2 価のフラグ メントが観測されるレーザー強度近傍かそれより少し低い強度 $\left(10^{12} \sim 10^{13} \mathrm{~W} / \mathrm{cm}^{2}\right)$ で実験を行った. 最近, 精力的に行われ ている高強度極短パルスレーザーによる解離性イオン化反応の 研究によると, 分子がイオン化した後, 分子イオンは強いレー ザー電場にさらされることにより非断熱解離が誘起され，分子 の回転周期より十分短い光パルスの時間幅内で解離することが 指摘されている19,20). したがって，イオン化から解離おこるま でのダイナミクスが観測データに影響を与える影響は小さいと 考えられる. またクーロン爆発の光解離生成物への寄与も小さ いと思われる。 
差 $\phi=\pi$ の場合，それぞれのイオンにおいて， $\mathrm{I}_{\mathrm{f}}$ と $\mathrm{I}_{\mathrm{b}}$ の大小 関係が完全に逆転していることわかる．この実験結果は，頭 と尻尾を区別して配向したフッ化メチル分子がイオン化, 検 出されており，位相制御レーザーパルスの相対位相差を 0 から にすることによって検出された分子の配向方向が反 転することを示している。

\section{4. 実験結果と考察}

4.1 ハロゲン化メチル $\left(\mathrm{CH}_{3} \mathrm{X} ; \mathrm{X}=\mathrm{F}, \mathrm{Cl}, \mathrm{Br}, \mathrm{I}\right)$

強い $(\omega+2 \omega)$ 位相制御レーザーパルスによる非共鳴イ オン化によって引き起こされる配向分子選択効果について系 統的に調べるため, 波動関数が系統的に変化する分子系（八 ロゲン化メチルとハロゲン化アリル）を用いた実験を行っ た ${ }^{8)}$.

四つのハロゲン化メチル $\left(\mathrm{CH}_{3} \mathrm{X} ; \mathrm{X}=\mathrm{F}, \mathrm{Cl}, \mathrm{Br}, \mathrm{I}\right)$ は Fig. 1 (b)左列に示されるように $\pi$ 型の HOMO を持つ ${ }^{8)}$. 八ロゲ ン原子のイオン化ポテンシャル $(\mathrm{F} ; 17.42 \mathrm{eV}, \mathrm{Cl} ; 12.97 \mathrm{eV}$, $\mathrm{Br} ; 11.81 \mathrm{eV}, \mathrm{I} ; 10.45 \mathrm{eV})$ を反映して, $\mathrm{CH}_{3} \mathrm{I}, \mathrm{CH}_{3} \mathrm{Br}, \mathrm{CH}_{3}$ $\mathrm{Cl}$ ではハロゲン側の波動関数の振幅が大きく, $\mathrm{CH}_{3} \mathrm{~F}$ のみメ チル基側の波動関数の振幅が大きくなる（ちなみに $\mathrm{CH}_{3}$ の イオン化ポテンシャルは $9.843 \mathrm{eV}$ ). Fig. 1(b)に示されるよ うにこの分子系は $\mathrm{CH}_{3} \mathrm{I}$ から $\mathrm{CH}_{3} \mathrm{~F} へ \mathrm{HOMO}$ の非対称性が 系統的に移り変わるという特徵を持つ. 一方, 永久双極子は 八ロゲン原子からメチル基に向いて扣，お抢よそ同じ大き さを示す $\left(\mathrm{CH}_{3} \mathrm{~F} ; 1.858 \mathrm{D}, \mathrm{CH}_{3} \mathrm{Cl} ; 1.896 \mathrm{D}, \mathrm{CH}_{3} \mathrm{Br} ; 1.820 \mathrm{D}\right.$, $\left.\mathrm{CH}_{3} \mathrm{I} ; 1.641 \mathrm{D}\right) . \mathrm{CH}_{3} \mathrm{X}$ 分子に単色のフェムト秒光パルス

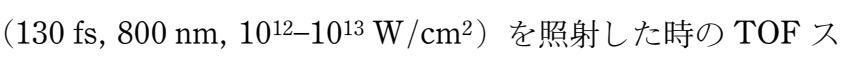
ペクトルをFig. 3(a)に示す. TOF スペクトルには解離性 イオン化反応によって, 主にハロゲンイオン, メチルイオ ン, 親分子イオンが観測される. $\mathrm{CH}_{3} \mathrm{X}$ 分子に $(\omega+2 \omega)$ 位 相制御フェムト秒光パルスを照射すると光解離生成物イオン の前方成分と後方放出成分に非対称性が観測された. Fig. 1 (a)で示したように位相制御レーザーパルスの相対位相を変 化させると, 光電場の非対称性が 0 と $\pi$ で反転し, その振 る舞いが $2 \pi$ の周期で繰り返される. 位相制御レーザーパル スの光電場の非対称と相関のある配向分子がイオン化された ならば, 光解離生成物イオンはその配向方向を反映して, 放 出方向が 0 と $\pi$ で反転し，その振る舞いが $2 \pi$ の周期で繰り 返されることが期待される. また 2 体解離においてある結 合に関する光解離生成物の対は，その結合に沿ってそれぞれ 逆方向に放出されることを反映して, 放出方向が抢互いに逆 位相の振る舞いをすることが期待される. Fig. 3(b)はそれ ぞれの光解離生成物の $\mathrm{I}_{\mathrm{f}} / \mathrm{I}_{\mathrm{b}}$ を相対位相差 $\phi$ の関数としてプ ロットしたものである. 解離生成物イオンは明瞭な $2 \pi$ の振 動を示し, 八ロゲンイオンとメチルイオンがお互いに逆位相 の関係にあることがわかった．この実験結果は，4つの $\mathrm{CH}_{3}$ $\mathrm{X}$ 分子で配向分子が検出され，相対位相差を 0 から $\pi$ にす ることによって検出された分子の配向方向が反転することを 示している8).

さらに, これらの分子の配向方向を決めるために, 混合気 体による測定を行った. $\mathrm{CH}_{3} \mathrm{I}$ を基準とした混合気体の測定 を行い，4つ分子の位相関係を確定する実験を行った．その (a)
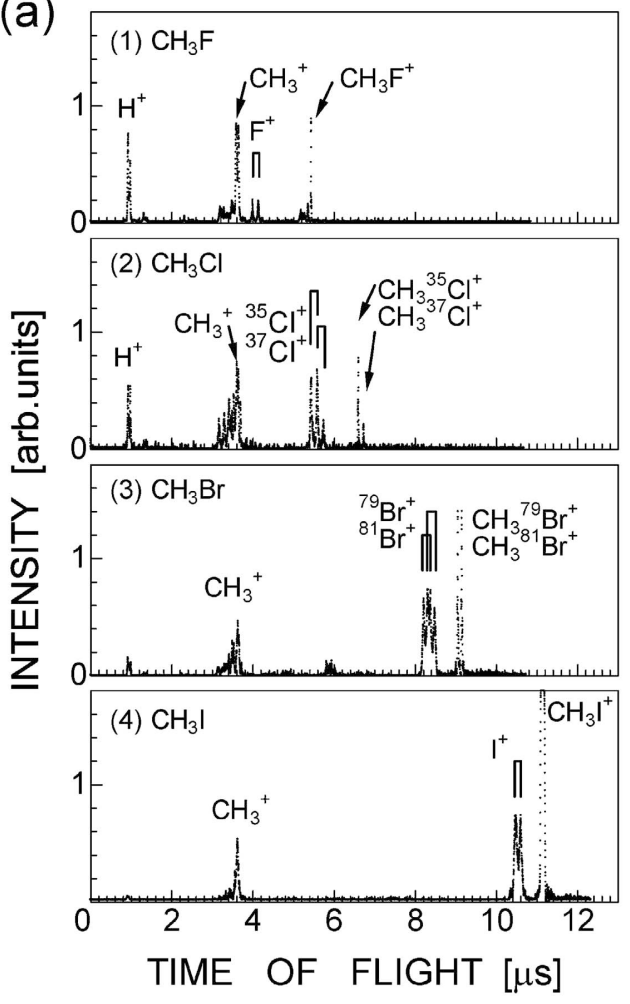

(b)

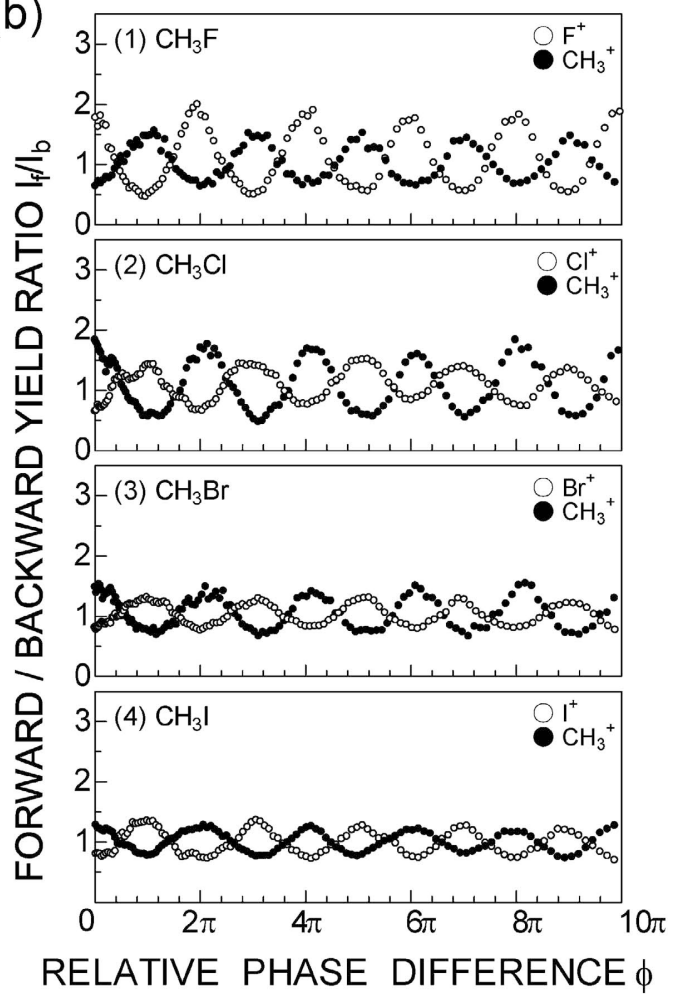

Fig. 3 (a) TOF mass spectra of ions generated by dissociative ionization of (1) $\mathrm{CH}_{3} \mathrm{~F}$, (2) $\mathrm{CH}_{3} \mathrm{Cl}$, (3) $\mathrm{CH}_{3} \mathrm{Br}$, and (4) $\mathrm{CH}_{3} \mathrm{I}$ irradiated with single frequency laser pulses $\left(800 \mathrm{~nm}, 130 \mathrm{fs}, 10^{12}-10^{13} \mathrm{~W} / \mathrm{cm}^{2}\right)$. The solid lines indicate the pairs of forward and backward peaks. (b) Forward/backward yield ratio $\left(I_{\mathrm{f}} / I_{\mathrm{b}}\right)$ as a function of relative phase difference $\phi$ : (open circles) halogen ion; (closed circles) $\mathrm{CH}_{3}^{+}$ cation. 
結果, $\mathrm{CH}_{3} \mathrm{~F}$ のフッ素イオンは $\cos$ 型, $\mathrm{CH}_{3} \mathrm{Cl}, \mathrm{CH}_{3} \mathrm{Br} . \mathrm{CH}_{3} \mathrm{I}$ のハロゲンイオンは, マイナス $\cos$ 型の振る舞いをすること がわかった (Fig. 3(b)の白丸).この実験結果は，4つの $\mathrm{CH}_{3} \mathrm{X}$ 分子の中で $\mathrm{CH}_{3} \mathrm{~F}$ のみ逆向きの配向方向の分子が検出 されていることを意味している. したがって, 検出された配 向分子の向きは HOMO の非対称性に相関があることを示し ており, 配向分子検出のメカニズムは, $(\omega+2 \omega)$ 位相制御 レーザーパルスの異方的光トンネルイオン化に基づく配向分 子選択イオン化が主要な効果であると結論づけられる のように $(\omega+2 \omega)$ 位相制御レーザーパルスは波動関数の レベルで分子の頭と尻尾を識別することが可能である.

ここでひとつ注意したいのは, 分子のトンネルイオン化を 記述する分子 ADK モデルによると, 光解離生成物の放出角 度分布は HOMO の空間形状を反映したものになるため ${ }^{13)}$, ハロゲン化メチルの系のように HOMO が $\pi$ 軌道の場合, そ の空間形状を反映したバタフライ型の放出角度分布が予想さ れることである. 実際に酸素分子でバタフライ型の光解離生 成物の放出角度分布が 8 フェムト秒の極短光パルスを使用 することによって観測されている16).さらに35フェムト秒 以上の時間幅の光パルスでは, 強い光電場とそれによって誘 起された分子分極との相互作用によって生じた動的な整列 （分子の頭と尻尾を区別しない分子軸だけの整列）効果によ って, HOMOの空間形状を反映した光解離生成物放出角度 分布から分子軸に偏った光解離生成物放出角度分布へ移り变 わることが報告されている16). 今回の筆者の行った実験
は, 光解離生成物の前方放出成分と後方放出成分しか区別し ていないため放出角度分布に関する情報は得られないが, 使 用したフェムト秒パルスは130 fs であることから動的な分子 整列効果も含んでいると考えられる. したがって, 本研究で 得られた結果は，ランダム配向の気体分子に打ける配向分子 選択イオン化というよりは, レーザー電場により動的に整列 した気体分子に抢ける配向分子選択イオン化である可能性が 高い.

\section{2 ハロゲン化アリル $\left(\mathbf{C}_{3} \mathbf{H}_{5} \mathbf{X} ; \mathbf{X}=\mathbf{F}, \mathbf{C l}, \mathbf{B r}, \mathbf{I}\right)$}

四つのハロゲン化アリル $\left(\mathrm{C}_{3} \mathrm{H}_{5} \mathrm{X} ; \mathrm{X}=\mathrm{F}, \mathrm{Cl}, \mathrm{Br}, \mathrm{I}\right)$ は Fig. 1 (b) 右列に示されるように, 炭素の 2 重結合を一つもち, HOMO は 2 重結合の周辺で波動関数の振幅が大きい．八ロ ゲン化メチル分子と同様に, ハロゲン原子のイオン化ポテン シャルを反映して $\mathrm{C}_{3} \mathrm{H}_{5} \mathrm{~F}$ から $\mathrm{C}_{3} \mathrm{H}_{5} \mathrm{I}$ に移り変わるにつれ て，八ロゲン原子の波動関数振幅が系統的に大きくなる.八 ロゲン化アリルは，2 重結合の部位とハロゲン原子で波動関 数の相対振幅が競合して系統的に変化する興味深い分子系で ある. $\mathrm{C}_{3} \mathrm{H}_{5} \mathrm{X}$ 分子に単色のフェムト秒光パルス (130 fs, $\left.800 \mathrm{~nm}, 10^{12}-10^{13} \mathrm{~W} / \mathrm{cm}^{2}\right)$ を照射した時の TOF スペクト ルを Fig. 4(a)に示す. 解離性イオン化反応によって, TOF スペクトルにはハロゲン化メチルと比較して様々な解離生成 物イオンと親分子イオンが観測される。 $\mathrm{C}_{3} \mathrm{H}_{5} \mathrm{X}$ 分子に $(\omega$ $+2 \omega)$ 位相制御フェムト秒光パルスを照射すると $\mathrm{C}_{3} \mathrm{H}_{5}^{+}$を 除く光解離生成物イオンの前方成分上後方放出成分に非対称 性が観測された. Fig. 4(b) は光解離生成物の $\mathrm{I}_{\mathrm{f}} / \mathrm{I}_{\mathrm{b}}$ を相対位 (a)
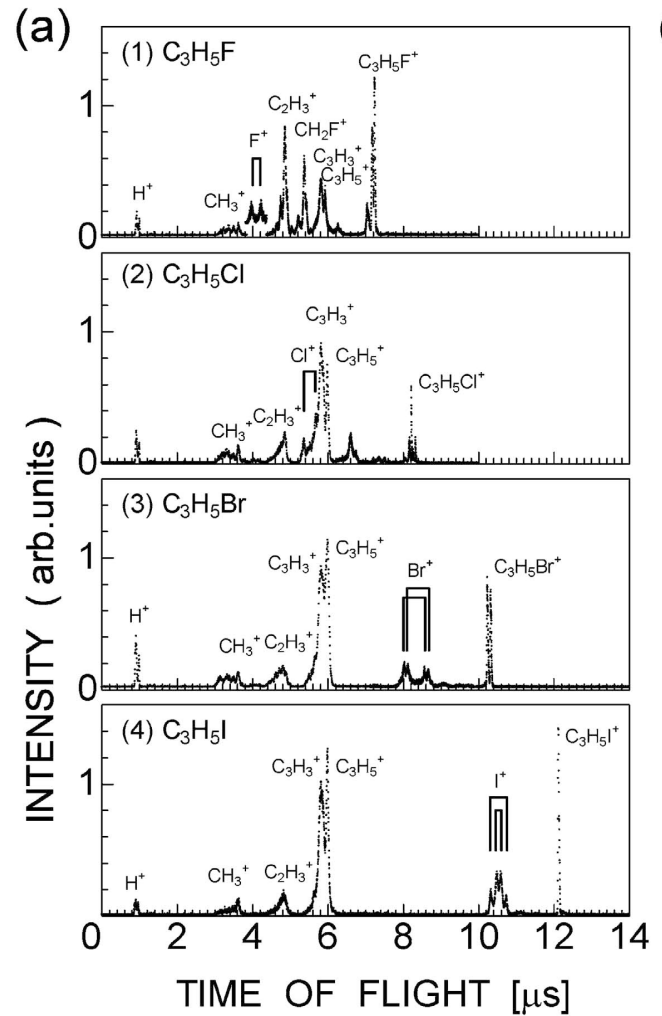

(b)

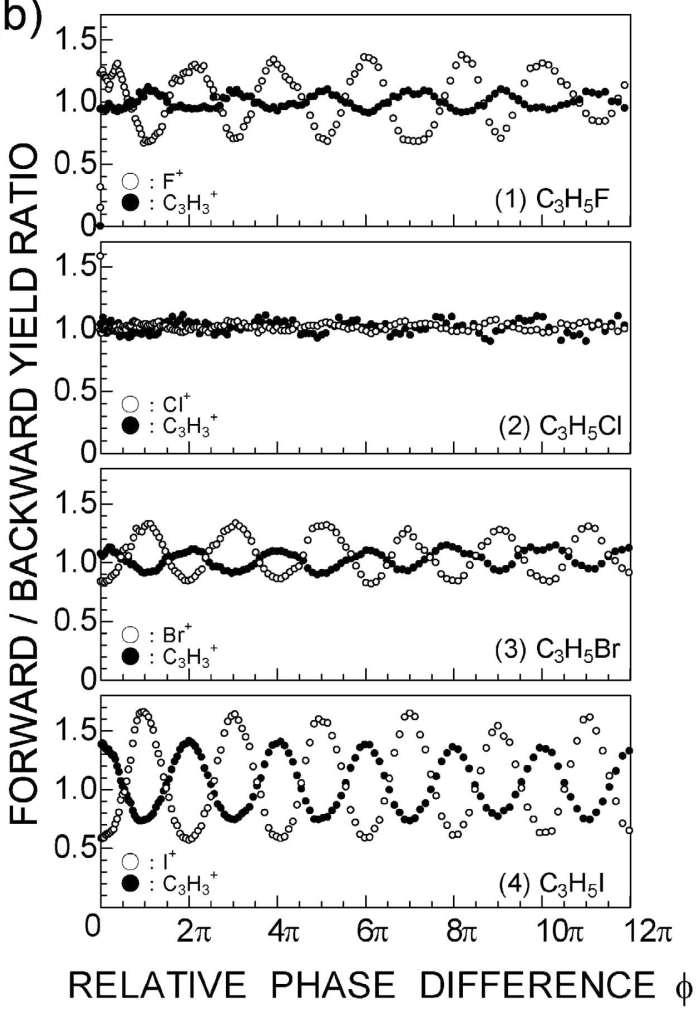

Fig. 4 (a) TOF mass spectra of ions generated by dissociative ionization of (1) $\mathrm{C}_{3} \mathrm{H}_{5} \mathrm{~F}$, (2) $\mathrm{C}_{3} \mathrm{H}_{5} \mathrm{Cl}_{\text {, }}(3) \mathrm{C}_{3} \mathrm{H}_{5} \mathrm{Br}$, and (4) $\mathrm{C}_{3} \mathrm{H}_{5} \mathrm{I}$ irradiated with single frequency laser pulses $\left(800 \mathrm{~nm}, 130 \mathrm{fs}, 10^{12}-10^{13} \mathrm{~W} / \mathrm{cm}^{2}\right)$. The solid lines indicate the pairs of forward and backward peaks. (b) Forward/backward yield ratio $\left(I_{\mathrm{f}} / I_{\mathrm{b}}\right)$ as a function of relative phase difference $\phi$ : (open circles) halogen ion; (closed circles) $\mathrm{C}_{3} \mathrm{H}_{3}^{+}$ cation. 
相差 $\phi$ 関数としてプロットしたものである. 解離生成物 イオンは明膫な $2 \pi$ の振動を示し八ロゲンイオンと $\mathrm{C}_{3} \mathrm{H}_{3}$ イ オンが抢互いに逆位相の関係にあることから，4つの $\mathrm{C}_{3} \mathrm{H}_{5} \mathrm{X}$ 分子で配向分子が検出されることがわかった ${ }^{9)}$. 八ロゲン原 子の結合の相手である $\mathrm{C}_{3} \mathrm{H}_{5}^{+}$に位相依存性が観測されなかっ た理由は以下のように推論できる. 最近の高強度極短パルス レーザーによる解離性イオン化反応の研究によると, 分子が イオン化した後, 分子イオンは強いレーザー電場にさらされ ることにより非断熱解離が誘起され, 分子の回転周期より十 分短い光パルスの時間幅内でイオン化時の配向方向を保存し たまま解離し, 解離生成物イオンは配向方向に放出され る $^{19,20)} \cdot \mathrm{C}_{3} \mathrm{H}_{3}^{+}$の $\mathrm{I}_{\mathrm{f}} / \mathrm{I}_{\mathrm{b}}$ が位相に依存することから，イオン 生成時に光パルスの時間幅内でハロゲン一炭素間の結合切断 に加え, 水素が 2 個取れる反応も促進されるようである.

観測された $\mathrm{C}_{3} \mathrm{H}_{5}^{+}$は, 光パルス通過後に親分子イオンがイオ ン化時の配向方向を保存していない時間領域で生成したもの か, 試料ガス中に $\mathrm{C}_{3} \mathrm{H}_{5}$ ラジカルとして存在していたものが イオン化されたものと考えられる.

さらに, これらの分子の配向方向を決に, 八ロゲ ン化メチルと同様に, 混合気体による測定を行った. $\mathrm{C}_{3} \mathrm{H}_{5} \mathrm{I}$ を基準とした混合気体の測定を行い，4つ分子の位相関係を 確定する実験を行った．その結果， $\mathrm{C}_{3} \mathrm{H}_{5} \mathrm{~F}$ のフッ素イオン は $\cos$ 型, $\mathrm{C}_{3} \mathrm{H}_{5} \mathrm{Cl}$ の塩素イオンは, 微弱な位相依存性であ るがマイナス $\cos$ 型, $\mathrm{C}_{3} \mathrm{H}_{5} \mathrm{Br}, \mathrm{C}_{3} \mathrm{H}_{5} \mathrm{I}$ のハロゲンイオンもマ イナス $\cos$ 型の振る舞いをすることがわかった（Fig. 4(b) の白丸).この実験結果は, 4 つの $\mathrm{C}_{3} \mathrm{H}_{5} \mathrm{X}$ 分子の中で $\mathrm{C}_{3} \mathrm{H}_{5} \mathrm{~F}$ のみ逆向きの配向方向の分子が検出されていることを意味し ている.したがって, 八ロゲン化メチル分子と同様, 検出さ れた配向分子の向きは波動関数の非対称性にある程度相関が あることを示して抢り, 配向分子検出のメカニズムは, $(\omega+2 \omega)$ 位相制御レーザーパルスの異方的光トンネルイオ ン化に基づく配向分子選択イオン化が主要な効果であること が示唆される.八ロゲン化アリル分子のような対称性の低い 分子でも配向分子選択イオン化が可能であるということが実 験的に示すことができたが，対称性が低いため異方性トンネ ルイオン化による配向分子選択イオン化の予測はそれほど単 純ではなく, 今後, 理論計算との比較が必要である ${ }^{14,15)}$.

\section{5. まと め}

基本波と第二高調波を重ね合わせその相対位相を精密に制 御した強い位相制御レーザーパルスによる気体分子の配向分 子選択イオン化について述べた。この手法は非対称な波動関 数と $(\omega+2 \omega)$ 位相制御レーザーパルスの非対称光電場々 の相互作用によって引き起こされる異方性光トンネルイオン 化に基づく空間領域での分子操作技術であることが明らかと なった．その特徵は以下のと抢りである. (1)通常のレーザー 光では困難であった分子の頭と尻尾を区別した分子操作が位 相制御レーザーパルスによって可能であり, 配向分子の向き を相対位相差 $\phi$ の符号 $(0, \pi)$ によって反転させることがで きる. 光電場の非対称性という位相制御レーザーパルスの持 つ新しい光の本質に基づく分子操作技術である. (2)共鳴遷移 を必要としないため光の波長を变える必要がなく分子の種類
に依存しない。(3)分子の極性や大きさの制約を受けない適応 範囲の広い汎用的な手法となる可能性がある. (4)分子の回転 温度にそれほど敏感でなく, 回転温度の高い分子線に対して も, 高い配向選択率が実現できる。

配向分子線の生成抢よびその応用という観点からは, 配向 分子選択イオン化は以下の点で不十分である. (1)外場のない 状態での中性の配向分子線を供給する手法ではない。(2)配向 分子選択イオン化はランダム配向の気体分子の一部をイオン 化して制御しているに過ぎず，また強い位相制御レーザーパ ルスでイオン化した分子は壞れることがある。したがって立 体化学等への適応場面は制限を受ける.

一方, 配向分子選択イオン化は分子と六極不均一電場との 相互作用を利用した配向分子線発生法やレーザー電場による 断熱打よび非断熱分子配向制御とはメカニズムが異なるた め, これらと組み合わせれば, 3 次元的分子配向操作技術へ 展開できることが期待される. 例えば, 六極不均一電場や強 いレーザー電場によって生成した配向分子線に対して, 配向 方向とは異なる方向で位相制御レーザーパルスによる配向分 子選択イオン化を行えば, 配向度の高い 3 次元的な配向分 子選択イオン化が実現できる可能性があるため, 実効的に 3 次元的な配向依存性に基づく立体効果を計測することのでき る手法への展開が期待される.

\section{〔文献〕}

1) H. Ohoyama: BUTSURI, 62 (2007) 360.

2) M. Okada: BUTSURI, 63 (2008) 205.

3) Y. Yamauchi, M. Kurahashi and T. Suzuki: OYO BUTURI, 71 (2005) 1346.

4) H. Sakai: BUTSURI, 64 (2009) 544.

5) H. Ohmura, T. Nakanaga and M. Tachiya: Phys. Rev. Lett., 92 (2004) 113002.

6) H. Ohmura and T. Nakanaga: J. Chem. Phys., 120 (2004) 5176.

7) H. Ohmura, N. Saito and M. Tachiya: Phys. Rev. Lett., 96 (2006) 173001.

8) H. Ohmura, F. Ito and M. Tachiya: Phys. Rev. A, 74 (2006) 043410.

9) H. Ohmura and M. Tachiya: Phys. Rev. A, 77 (2008) 023408.

10) H. Ohmura, N. Saito, H. Nonaka and S. Ichimura: Phys. Rev. A, 77 (2008) 053405.

11) H. Ohmura: LASER KENKYU, 37 (2009) 16.

12) H. Ohmura: HIKARIKAGAKU, 40 (2009) 2.

13) L. V. Keldysh: Sov. Phys. JETP, 20 (1965) 1307.

14) X. M. Tong, Z. X. Zhao and C. D. Lin: Phys. Rev. A, 66 (2002) 033402

15) C. D. Lin and X. M. Tong: J. Photochem. Photobio. A: Chem., 182 (2006) 213.

16) A. S. Alnaser, S. Voss, X.-M. Tong, C. M. Maharjan, P. Ranitovic, B. Ulrich, T. Osipov, B. Shan, Z. Chang and C. L. Cocke: Phys. Rev. Lett., 93 (2004) 113003.

17) M. Uiberacker, Th. Uphues, M. Schultze, A. J. Verhoef, V. Yakovlev, M. F. Kling, J. Raushenberger, N. M. Kabachnik, H. Schröder, M. Lezius, K. L. Kompa, H.-G. Muller, M. J. J. Vrakking, S. Hendel, U. Kleineberg, U. Heinzmann, M. Drescher and F. Krausz: Nature, 446 (2007) 627.

18) P. Eckle, A. N. Pfeiffer, C. Cirelli, A. Staudte, R. Dörner, H. G. Muller, M. Büttiker and U. Keller: Science, 322 (2008) 1525.

19) R. Itakura, K. Yamanouchi, T. Tanabe, T. Okamoto and F. Kannari: J. Chem. Phys., 119 (2003) 4179.

20) H. Kono and Y. Sato: Chem. Phys., 304 (2004) 203. 